\title{
Climate change and the health impact of aflatoxins exposure in Portugal - an overview
}

Assunção, Ricardo; Martins, Carla; Viegas, Susana; Viegas, Carla; Jakobsen, Lea Sletting; Pires, Sara Monteiro; Alvito, Paula

Published in:

Food Additives \& Contaminants: Part A - Chemistry, Analysis, Control, Exposure \& Risk Assessment

Link to article, DOI:

$10.1080 / 19440049.2018 .1447691$

Publication date:

2018

Document Version

Peer reviewed version

Link back to DTU Orbit

Citation (APA):

Assunção, R., Martins, C., Viegas, S., Viegas, C., Jakobsen, L. S., Pires, S. M., \& Alvito, P. (2018). Climate change and the health impact of aflatoxins exposure in Portugal - an overview. Food Additives \& Contaminants: Part A - Chemistry, Analysis, Control, Exposure \& Risk Assessment, 35(8), 1610-1621.

https://doi.org/10.1080/19440049.2018.1447691

\section{General rights}

Copyright and moral rights for the publications made accessible in the public portal are retained by the authors and/or other copyright owners and it is a condition of accessing publications that users recognise and abide by the legal requirements associated with these rights.

- Users may download and print one copy of any publication from the public portal for the purpose of private study or research.

- You may not further distribute the material or use it for any profit-making activity or commercial gain

- You may freely distribute the URL identifying the publication in the public portal 


\title{
Climate change and the health impact of aflatoxins exposure in Portugal - an overview
}

\author{
Ricardo Assunção, Carla Martins, Susana Viegas, Carla Viegas, Lea S. \\ Jakobsen, Sara Pires \& Paula Alvito
}

To cite this article: Ricardo Assunção, Carla Martins, Susana Viegas, Carla Viegas, Lea S. Jakobsen, Sara Pires \& Paula Alvito (2018): Climate change and the health impact of aflatoxins exposure in Portugal - an overview, Food Additives \& Contaminants: Part A, DOI: 10.1080/19440049.2018.1447691

To link to this article: https://doi.org/10.1080/19440049.2018.1447691

View supplementary material $₫$

Accepted author version posted online: 01 Mar 2018.

Submit your article to this journal

Џ Article views: 11

Q View related articles ¿

View Crossmark data $₫$ 
Publisher: Taylor \& Francis \& Informa UK Limited, trading as Taylor \& Francis

Journal: Food Additives \& Contaminants: Part A

DOI: $10.1080 / 19440049.2018 .1447691$

\title{
Climate change and the health impact of aflatoxins exposure in Portugal - an overview
}

Ricardo Assunção ${ }^{\mathrm{a}, \mathrm{b}, *}$, Carla Martins, ${ }^{\mathrm{a}, \mathrm{b}, \mathrm{c}}$, Susana Viegas ${ }^{\mathrm{d}, \mathrm{e}}$, Carla Viegas ${ }^{\mathrm{d}, \mathrm{e}}$, Lea $\mathrm{s}$ Jakobsen $^{\mathrm{f}}$, Sara Pires ${ }^{\mathrm{f}}$ and Paula Alvito ${ }^{\mathrm{a}, \mathrm{b}}$

${ }^{a}$ Food and Nutrition Department, National Institute of Health Dr. Ricardo Vorge, Portugal; ${ }^{b}$ CESAM, Centre for Environmental and Marine Studies, Univer sity of Aveiro, Portugal; ${ }^{c}$ NOVA National School of Public Health Universidade NOVA de

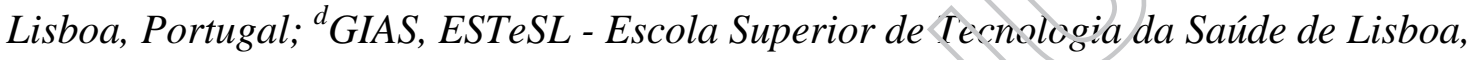
Instituto Politécnico de Lisboa, Lisbon, Portugal; ${ }^{e}$ Centro de Ínvestigação em Saúde Pública, Escola Nacional de Saúde Pública, Universidade NOVA de Lisboa, Portugal;

${ }^{f}$ Division for Diet, Disease Prevention and Toxicology, The National Food Institute, Technical University of Denmark, Dełmark

* Corresponding author email: ricardo.assuncao@insa.min-saude.pt

\begin{abstract}
Climate change has been indicated as a driver for food safety issues worldwide, mainly due to the impact on the occurrence of food safety hazards at various stages of focd chain. Mycotoxins, natural contaminants produced by fungi, are among the most important of such hazards. Aflatoxins, which have the highest acpite an chronic toxicity of all mycotoxins, assume particular importance. A recent study predicted aflatoxin contamination in maize and wheat crops in Furope within the next 100 years and aflatoxin B1 is predicted to become a food safety issue in Europe, especially in the most probable scenario of climate change $\left(+2{ }^{\circ} \mathrm{C}\right)$. This review discusses the potential influence of climate change on the health risk associated to aflatoxins dietary exposure of Portuguese population. We estimated the burden of disease associated to the current aflatoxin exposure for Portuguese population in terms of Disability Adjusted Life Years (DALYs). It is expected that in the future the number of DALYs and the associated cases of
\end{abstract}


hepatocellular carcinoma due to aflatoxins exposure will increase due to climate change. The topics highlighted through this review, including the potential impact on health of the Portuguese population through the dietary exposure to aflatoxins, should represent an alert for the potential consequences of an incompletely explored perspective of climate change. Politics and decision-makers should be involved and committed to implement effective measures to deal with climate change issues and to reduce its possible consequences. This review constitutes a contribution for the prioritisation of strategies to face the unequal burden of effects of weather-related hazards in Portugal and across Europe.

Keywords: climate change, aflatoxins, risk assessment, health-impact, Portugal

\section{Introduction}

The Fifth Assessment Report of the Intergovernmertal Panel on Climate Change (IPCC) states that "warming of the climate system is unequivocal, and since the 1950s, many of the observed changes are unprecedented over decades to millennia. The atmosphere and ocean have warmed, the amounts of snow and ice have diminished, and sea level has risen" (JFCC 2914), According to this report, in recent decades, changes in climate have causfa inipacts on natural and human systems on all continents and across the oceans (IFCC 2014). Climate change has become one of the most critical issues for the sustainabledevelopment of human societies and the functioning of ecosystems on errth (yan der Fels-Klerx et al. 2012). Given the potential of climate change to reverse the health gains from economic development, and the health co-benefits that accrue from actions for a sustainable economy, climate change constitutes one of the biggest global threats to human health of the 21st century (Watts et al. 2015). At the Conference of Parties in Paris (COP21), in December 2015, negotiators from 195 countries agreed to "pursue efforts to limit the (global average) temperature increase to $1.5{ }^{\circ} \mathrm{C}$ above pre- 
industrial levels", recognizing that this would significantly reduce the risks and impacts of climate change (UNFCCC 2015). Nevertheless, projected climate change effects will undoubtedly influence primary agricultural systems, including animal and plant production, and thus food availability (Van der Fels-Klerx et al. 2016). These projected climate change effects include a global air temperature increase, variation in precipitation, drought and the atmospheric carbon dioxide accumulation. These effects constitute some of the main concerns for agriculture and food safety connected to the climate change (Van der Fels-Klerx et al. 2016). The potential impact of climate change on food security is a widely debated and investigated issue. Noneiheless, the specific impact on safety of food and feed has remained a less stuaied topic (Miraglia et al. 2009; Tirado et al. 2010). Climate change is also likely to increase the risk of food contaminants through the tendency to increase the use of agrochemicals to balance the effects of more frequent extreme weather events and water scarcity in some regions (Santos 2017). Portugal is highly vulnerable to climate change impacts due to its geographical situation at the ex.reme southwestern part of Europe (Carvalho et al. 2014; Campos et al. 2017). Chinate change impacts in Portugal result from a decreasing annual precipitation, more intense extreme weather and climate events (e.g. heat waves and droughts . Traditionally, the Portuguese climate is considered as Mediterranean, characterizes by warm and dry summers and cool and wet winters. The mean annual air eimperature varies between $7{ }^{\circ} \mathrm{C}$ in the inner highlands of central Portugal and $18{ }^{\circ} \mathrm{C}$ in the southern coast. The mean annual precipitation is around $900 \mathrm{~mm}$ with a strong north-south gradient, reaching values of $3000 \mathrm{~mm}$ in the northwest mountains and values below $500 \mathrm{~mm}$ in the south-eastern part of the country (Carvalho et al. 2014). In Portugal, studies have been revealing periods of warming similar to global temperature behaviour. Ramos et al. (2011) studied the evolution of extreme temperatures over 
Portugal, and in the period of 1976 - 2006, the authors verified that the annual mean temperature in the country increased by $0.52{ }^{\circ} \mathrm{C}$ per decade, which is more than double the rate of mean annual global temperature increase. Fonseca et al. (2016) described the recent trends of extreme temperature indices for the Iberian Peninsula and reported an increase in the number of warm days and warm nights, especially during summer. Eight of the ten warmest years occurred in the last 20 years and heat waves have becoming more frequent since the beginning of this century (Ramos et al. 2011). All these observations are consistent with a tendency of more intense and frequent extreme weather and climate events. The observed trends are very similar to those projected by the future climate scenarios as regards both temperature and precipitation (Carvalho et al. 2014). In fact the Mediterranean region, including mainland Portugal, was considered a climate change hotspot (Giorgi 2006)

Climate change may have an impact on the ccurrence of food safety hazards at various stages of the food chain, from priniary production through to consumption (Tirado et al. 2010). Both cherical and microbiological risks are foreseen to impair food and feed safety as a consequerice of climate change: in particular mycotoxins, marine biotoxins (phycotoxins), pesticide residues, trace metals, among others (Miraglia et al. 2009). The expected impact of climate change on the presence of mycotoxins in food and feed is of great concern (Paterson \& Lima 2010; Paterson \& Lima 2011; Battilari et al. 2016). Due to the public health and economic implications, the legislated myeotoxins are aflatoxins, ochratoxin A (OTA), deoxynivalenol (DON), fumonisins, zearalenone and patulin (European Commission 2006). Some of the main health toxic effects of mycotoxins include liver cancer or hepatocellular carcinoma (HCC) (aflatoxins), oesophageal cancer and neural tube defects (fumonisins), immunotoxicity and gastroenteritis (DON and other trichothecenes), and renal diseases (OTA) (Wu et al. 
2014). Economic implications of mycotoxin contamination include trade disruptions due to recall or rejection of products; this food safety hazard accounted for 489 notifications on mycotoxins in food, most related to the presence of aflatoxins in 2016 (European Commission 2017).

The most toxic mycotoxins are aflatoxins, which can occur in host crops infected by some species of Aspergillus spp. (Wu et al. 2014). Aflatoxins are genotoxic, carcinogenic and immunosuppressive substances, and cause both acute and chronic toxicity. HCC is the third leading cause of cancer deaths worldwide (WHO 2008). Due to its carcinogenic and genotoxic effects, mixes of aflatoxins have beenclassified as Group 1 (carcinogenic to humans) by the International Agency for Fesearch on Cancer (IARC 2012). The four major aflatoxins are known as $B_{1}, B_{2}, G_{1}$, and $G_{2}$. Aflatoxin $B_{1}$ $\left(\mathrm{AFB}_{1}\right)$ is the most potent (in some species) naturally occurring chemical liver carcinogen known. Maize contamination is of ver high concern since this crop plays a main role both in food and feed supply workwide. Additionally, when animals that are intended for dairy production consume aflatoxin-contaminated feed, a metabolite, aflatoxin $\mathrm{M}_{1}$, is excreted in the mill (Strosnider et al. 2006). Aflatoxins are reported in several agricultural crops, manly maize, peanuts, pistachio nuts and cottonseeds (CAST 2003). The pessible change in patterns of aflatoxin occurrence in food and feed crops due to chinate change is a matter of concern that may require anticipatory actions (Pattilani et al. 2016). Until a few years ago, aflatoxins had not been signalled as a matter of concern for primary production in Europe (Logrieco \& Moretti 2008). However, in 2003, 2012 and 2015 several reports from Southern-eastern Europe countries identified an alarming contamination in maize (Piva et al. 2006; Tabuc et al. 2009; Levic et al. 2013; Dobolyi et al. 2013; Kos et al. 2013; Pleadin et al. 2014; Dimitrieska-Stojković et al. 2016; Janić Hajnal et al. 2017). 
In Portugal, previous studies have demonstrated the occurrence of aflatoxins in food products consumed by the Portuguese population (Alvito et al. 2010; Rodrigues et al. 2012; Martins et al. 2018) and exposure to aflatoxins through food (Assunção et al. 2015) and occupational exposure in different occupational environments (Viegas et al. 2012; Viegas et al. 2013a; S. Viegas et al. 2014; S. Viegas et al. 2016). Few published studies describe changes in the burden of climate-sensitive diseases in Portugal in response to changes in weather and climate, as assessed by Casimiro et al. (2006). According to the National Assessment of Human Health Effects of Climate Change in Portugal (Casimiro et al. 2006), the annual heat-related death rates in Lisbon may increase from between 5.4 and 6 per 100,000 in 1980-1998 to bet veen 8.5 and 12.1 by the 2020 s and to a maximum of 29.5 by the 2050s, if no adaptations occur. Recent catastrophes resulting from summer high temperatures and reduced air humidity in Portugal that took the form of severe and dramatic forest fires with significant consequences including loss of human lives (Jones 2017). The impact of climate change on these events remains unknown. Considering the potential consequences of climate change on food safety, particylarly in mycotoxin contamination of food products available in Portugal, this review discusses the potential influence of climate change in the health risk associated to aflatoxins dietary exposure of Portuguese population.

\section{Eriviyonmental conditions modulating mycotoxin exposure}

Although there are many factors involved in mycotoxins production by fungi, the climate is the most important (Magan et al. 2011; Milani 2013). Climate changes and their consequences on fungal dissemination are critical aspects of human exposure to mycotoxins (Magan et al. 2011; Milani 2013; Battilani et al. 2016). Effects of climate change on fungal species distribution and activity are difficult to predict because they are influenced in many different ways, such as: fungal characteristics, host features and 
availability, and competitive interactions between microbiota. In addition, environmental variables such as temperature, water availability and atmospheric $\mathrm{CO}_{2}$ and the interaction of these variables make it difficult to predict their influence on fungal distribution (Boddy 1984) and, consequently, mycotoxins presence in food and feed (IPCC 2007).

Mycotoxins are profoundly dependent on climate, plant and storage-associated problems, and also influenced by non-infectivity factors (e. g. bioavailability of (micro)nutrients, insect damage, and other pests attack), that are also driven by climatic conditions. Therefore, climate represents the crucial factor for agio-ecosystem powering fungal colonization and mycotoxin production (Magan et al. 2011).

Increasing temperatures are known to beneficiate the proliferation of several fungal species with toxigenic potential, namely. Fusarium graminearum complex (Miller 2008; Miraglia et al. 2009; Tirado et al. 2010), Fusarium verticilloides complex (Munkvold \& Desjardins 1997; Tirado et al. 2010; Paterson \& Lima 2011) and Aspergillus genus (Robens \& Cardvell 2003). Among Aspergillus genus, Aspergillus section Flavi is also facilitated by this climate scenario (Payne 1998; Bunyavanich et al. 2003; Paterson \& Lina 2010; Baranyi et al. 2015).

It has already been reported that European countries with temperate climates have a higher risk of exposure to fungal burden comprising fungi and mycotoxins (Paterson \& Lima 2011). The climate of these countries will most likely become warmer reaching temperatures of $33{ }^{\circ} \mathrm{C}$, which is very close to the optimum for atlatoxins production, among other mycotoxins (Paterson \& Lima 2011).

Lately, a wide incidence prevalence of aflatoxins contamination was reported in several crops from Southern-eastern European countries and can be associated with climate change (dry conditions and increased ambient temperatures) in those countries 
(Blaney et al. 2008; Tabuc et al. 2009; Levic et al. 2013; Dobolyi et al. 2013; Kos et al. 2013; Pleadin et al. 2014; Leggieri et al. 2015; Dimitrieska-Stojković et al. 2016; Janić Hajnal et al. 2017). Aspergillus section Flavi, the key fungus for aflatoxin production, is well adapted to warm and dry weather conditions (Payne 1998; Paterson \& Lima 2010; Baranyi et al. 2015). Although crops from tropical and/or sub-tropical areas are affected more commonly and severely by aflatoxin contamination, this can be changed dye to climate change, and temperate areas like Southern-eastern European countries covid also be affected (Battilani et al. 2016). Therefore, and due to the predicted temperature increase, Aspergillus section Flavi growth and consequently aflatoxin $B_{1}$ production, will be boosted (Paterson \& Lima 2010; Baranyi et al. 2015; Battilani et al. 2016). In Portugal, previous papers have already reported $A F{ }_{1}$ and $A F M_{1}$ in flours and dairy products, respectively (Alvito et al. 2010; Abrunbosa et al. 2016). Other aflatoxins have also been reported in wide variety of food preducts such as spices, honey, almonds, peanuts, hazelnuts, dry figs, pistachio nuts, raisins, pig liver and corn (Abrunhosa et al. 2016). In 2008, a published overview regarding Portuguese feed contamination (Martins et al. 2008) reported that $13 \%$ of the 513 raw materials samples analysed between the periods of 2000 to 2007 presented $\mathrm{AFB}_{1}$ contamination. The same authors described that $28 \%$ of the 1534 feed samples collected in the same period showed $\mathrm{AFB}_{1}$ contanination, being the most reported mycotoxin despite other mycotoxins were also measured (Martins et al. 2008). The higher prevalence of this Aspergillus section already observed in different Portuguese occupational environments, such as animal production (Sabino et al. 2012), waste sorting plant (C. Viegas et al. 2014) and feed industry (C. Viegas, Faria, et al. 2016 ) is of note. Moreover, occupational exposure to Aflatoxin $B_{1}$ in poultry, swine and in waste treatment plants has been reported (Viegas et al. 2012; Viegas et al. 2013b; 
Viegas et al. 2013a; Viegas et al. 2015). This can imply, besides an increasing problem of food safety, a growing problem in specific occupational settings due to climate change (C. Viegas, Meneses, et al. 2016).

\section{Dietary exposure levels of Portuguese population to mycotoxins}

Considering that aflatoxins are recognized as carcinogenic mycotoxins (Internationai Agency for Research on Cancer 2002), the continuous monitoring of the population exposure is of utmost importance, permitting the identification of grsuns potentially more exposed and consequently more vulnerable. Due to the constraints of exposure assessment through the human biomonitoring studies and with the indirect approach where occurrence data in food is combined with consunption data (Choi et al. 2015; Heyndrickx et al. 2015; de Nijs et al. 2016; Assunçăo et al. 2016), the main efforts should be focused on the development of studies that gather the biomonitoring evaluation with validated bionakers with food consumption and occurrence in food data, as recommended by EFSA (EFSA 2010).

Studies publi hed in the last ten years (2007-2017) on the Portuguese dietary exposure to aflatox ins and their occurrence in food are presented in

Table 1 and revealed that the population is exposed through food consumption. Despite the importance of aflatoxins as carcinogenic compounds, there are not many as ailable and reported studies in Portugal concerning the exposure of the Portuguese population. There were no reports available for the assessment of exposure to aflatoxins using human biomonitoring regarding the Portuguese population. In addition, there is a lack of data regarding the weather conditions and their effects on the frequency of aflatoxins contamination. 
(Table 1)

The reports presented in

Table 1 assessed the presence of aflatoxins in a wide variety of food products (e.g. dairy products, baby foods, breakfast cereals) and confirm that the occurrence of these mycotoxins is a reality in food products marketed in Portugal (Martins et al. 2007; Alvito et al. 2010; Duarte et al. 2013; Martins et al. 2018). Alvito et al. (2010) and Martins et al. (2018) highlighted the co-occurrence of mycotoxins, including aflatoxins. Duarte et al. (2013) also reported two milk samples above the legisiative l)mits (50 $\mu \mathrm{g} / \mathrm{L})$ (European Commission 2006; Duarte et al. 2013).

Cereals are raw materials that are very prone to mycotoxins contamination, including maize that was identified previously as a matrix susceptible to be contaminated in a climate change scenario (Eatilan; et al. 2016). Breakfast cereals analysed in Portugal included maize in their composition revealing the potential of being affected by the climate change. Interestingly, some studies reported $\mathrm{AFM}_{1}$ in cereal-based products; it is possible to hypothesize that the origin of this contamination is the presence of small amovnts of milk in the final product, indicating that feed grown locally is contaminated with $\mathrm{AFB}_{1}$. In spite of some food products referred in Table 1 are originated from regions of the world where the climatic conditions are already prtimal for fungal growth, it is expected that in the future, samples originated from Portugal could represent a higher risk with increased temperatures.

The exposure assessment estimates presented in

Table 1 referred to studies that applied the indirect approach, gathering occurrence in food and consumption data. In the performed studies, different scenarios 
were considered regarding the statistical treatment of non-detects $(<\mathrm{LOD})$ in accordance with the EFSA recommendations (European Food Safety Authority 2010), and deterministic and probabilistic methodologies were used. In general, these studies confirmed that the Portuguese population is exposed to aflatoxins and since there is no TDI (Tolerable Daily Intake) for aflatoxins (the ALARA principle, As Low As Reasonably Achievable, is applied as proposed by EFSA), it is not possible to evaluate the closeness to any reference value. However, when comparing to the French PD? (Probable Daily Intake) estimated by Leblanc et al. (2005), the Portuguese PD) for aflatoxins estimated by Abrunhosa et al. (2016) was about five tirnes higher (Leblanc et al. 2005; Abrunhosa et al. 2016). Assunção et al. (2015) aiso characterized the risk associated with this exposure; $\mathrm{AFB}_{1}$ revealed a margin of sxposure $(\mathrm{MoE})$ below 10,000 suggesting potential health concern for the high percentiles of intake (P90, P95 and P99) (European Food Safety Authority 2013, Assunção et al 2015).

These presented studies highlighted the lack of data on the occurrence of aflatoxins in foodstuffs and the consequent exposure of the Portuguese population. Our review also identified the absence of human biomonitoring studies regarding these mycotoxins and metabolites. In Portugal, and despite that the levels of occurrence of mycotoxins a low, it is expected that climate change will potentially increase its production, raising the risk of exposure, similarly to the situation of other Southerneastern Eurspean countries. Future efforts should be put in motion for a continuous surveillance, allowing for the identification of more susceptible population groups and for the prediction of the possible effects of climate and contamination patterns changes.

\section{Burden of disease caused by dietary exposure to aflatoxins in Portugal}

Burden of disease measures the impact that a disease represents on society in terms of mortality, morbidity and disability. Several measures can be applied to estimate the 
burden of disease, one of the most-used being Disability Adjusted Life Years (DALY). DALY provides a metric to compare the health impact of various diseases, injuries and risk factors, by integrating in a single measure the quantification of the burden of diseases (Murray \& Lopez 2013; Murray \& Lopez 2017). One DALY is equivalent to one year of healthy life lost. DALYs are calculated by adding the adjusted number of years lived with disability (YLDs) and the number of years of life lost due to prentiature mortality (YLLs), through YLD = Number of incident cases $x$ Duration until remission or death $x$ Disability Weight and YLL $=$ Number of deaths $x$ Residual life expectancy at the age of death (Devleesschauwer et al. 2015).

Food contaminants, including mycotoxins, among which particularly aflatoxins, are considered a worldwide health concern (Gibb et al. 20:5). Dietary aflatoxin exposure is considered a significant risk factor for hepatocellular carcinoma (HCC) or liver cancer (Wild \& Gong 2010). Liver cancer is the fifth most common cancer in men and the ninth most common cancer in women and is the second most common cause of death from cancer worldwide, estinated to have been responsible for nearly 746,000 deaths in 2012 (9.1\% of all sancer aeaths that year) (IARC/WHO 2016). In Portugal, the last available statistics revealed 1,133 deaths due to liver cancer in 2015 (INE 2016). The prognesis for iver cancer is very poor (with an overall ratio of mortality to incidence of 0.95 ), so the geographical patterns in incidence and mortality are very firmilar (IAR.C/WHO 2016).

A model was developed to estimate the health impact of dietary aflatoxins exposure of the Portuguese population, estimated number of cases of HCC and DALYs attributed to aflatoxins exposure (Table 2). The details of the model are described in the supplemental material.

(Table 2) 
Because different levels of aflatoxin intake could characterize the dietary exposure of the Portuguese population (i.e. the national exposure levels reported by Abrunhosa et al. (2016) and the European levels suggested by EFSA (2007)), the corresponding number of annual extra cases of HCC ranged from 0.52 and 2.00 was estimated (Table 2). Similarly, DALYs were derived for the same levels of aflatoxins exposure and for the Portuguese population an annual DALY could range between $9 . \mathrm{Q}$ and 30.9 (Table 2). Depending on the level of exposure, a range between 0 ng and $0.3 \mathrm{e}$ DALY/100,000 could be due to Portuguese dietary exposure to aflatoxins (Tab) 1s:2). Little previous work has estimated the burden of disease associated to al atoxin exposure using DALYs and none was previously reported in Portugal. Liu and $\mathrm{Wu}$ (2010) determined the global burden of HCC attributabic to aflatoxin exposure. The authors reported that of the 550,000-600,000 new cases worldwide each year, about 25,200-155,000 may be attributable to aflatoxin exposure, and the most cases occur in sub-Saharan Africa, Southeast Asia and Cinura. This study did not derive the associated DALYs. More recently, a WHO report by the Foodborne Disease Burden Epidemiology Reference Group (FER.G estrmates the global burden of foodborne diseases using DALYs, including for aflatoxins exposure (World Health Organization 2015). In their report, FER.G estinated a global number of foodborne illnesses, deaths and DALYs for aflatoxins of: 2 i $757 ; 19,455$; and 636,869, respectively (WHO 2015; Havelaar et al. 2015). This study also estimated the burden of disease for each of 14 subregions, including Portugal in the group named EUR A (with other countries from Europe, such as Spain, France, Greece and Italy). The study reported a median rate of 0.3 DALYs/100,000 population for the EUR A subregion. This is similar to our estimates of a maximum of 0.3 DALYs/100,000. Our model has several limitations, mainly due to uncertainties in the data used (e.g. aflatoxins exposure levels). Our estimates are 
probably conservative, i.e., underestimates rather than overestimates. For example, simultaneous health outcomes that could co-occur and consequently affect the associated DALYs or other than cancer outcome as a consequence of aflatoxins exposure, were not taken into account. Despite the data gaps and limitations, this study presents the first estimates of the burden of disease of Portuguese dietary aflatoxins exposure and should serve as an important starting point to evaluate the health impact of this type of exposure and also to infer about potential consequences of some factors that could interfere with Portuguese dietary exposure to aflatoxins, as climate change.

\section{Climate change and the associated health risk of Portuguese dietary aflatoxins exposure}

In terms of food safety, and by means of climate prediction models and scenario studies, scientists attempt to predict the consequence of the observed changes in order to advise policy-makers of the best strategy te circunivent the anticipated problems (Miraglia et al. 2009). In addition to the impact on the agriculture, food safety consequences namely the impact on the livestock production, the occurrence of certain microalgae in seas and oceans and consequenily their phycotoxins, the occurrence of residues of pesticides, persistent contaninants and pathogenic microorganisms, and the production of mycotoxins by moulds growing on crops have aroused the interest of worldwide scientific community (Miraglia et al. 2009). Paterson and Lima (2011) in their review concerning the further mycotoxin effects from climate change referred increased levels of aflatoxin, ochratoxin A from Aspergillus spp., and fumonisins in sub Mediterranean countries (e.g. North Portugal) as the temperature increases. In Southern and SouthEastern Europe (i.e. Portugal, Spain, Southern France, Italy, Slovenia, Greece, Malta, Cyprus, Bulgaria, and Southern Romania) as a consequence of temperature increase (in 
the order of $4-5^{\circ} \mathrm{C}$ ) and reduced water availability in summer, some effects are expected, namely a decrease in the agricultural yields (in the range of $10-30 \%$ in many regions), drought, heat waves, degradation of soil and ecosystems, and desertification (Paterson \& Lima 2011). Directly or indirectly, it is expected that these factors could interfere with fungi growth and mycotoxins production. In Europe, a pioneer research project has addressed quantitatively the potential impact on aflatoxin contamination of cereal grains (Van der Fels-Klerx et al. 2016). MODMAP-AFLA, a research project addressing a model approach to predict the future aflatoxin contamination of maize produced in Europe, considered three different climate scenarios (the present, $+2{ }^{\circ} \mathrm{C}$ and $+5^{\circ} \mathrm{C}$ ) (Battilani et al. 2012). MODMAP-AFLA revealed an estinated increase of aflatoxin contamination of maize, mainly in the $+29 \mathrm{C}$ scenario, with an increase of $\mathrm{AFB}_{1}$ contamination in the southern European countries. More recently, Battilani et al. (2016) studied the estimated aflatoxin contarnination in maize and wheat crops, within the next 100 years, under $+2^{\circ} \mathrm{C}$ and $+5^{\circ} \mathrm{C}$ chimate change scenarios. The authors reported that $\mathrm{AFB}_{1}$ is predicted to become a food safety issue in maize in Europe, especially in the $+2{ }^{\circ} \mathrm{C}$ scenario. which is the most probable scenario of climate change for the next years. Rased on the results obtained by these authors, the most concerned areas with an increase of aflatoxin contamination were: Eastern Europe, Balkan Peninsula and the Mediterranean regions including Portugal. Based on their results, Battilari et al. (2016) also referred that aflatoxin contamination above the legal limit are expected to become more frequent in the future. The potential ways that the health of the Portuguese population could be affected should be taken into account. As estimated by MODMAP-AFLA, climate change will affect Southern Europe, including Portugal. Aflatoxins could represent a significant issue in the future (Battilani et al. 2016). Considering the results on the aflatoxins estimated exposure levels in Portugal ( 
Table 1) and the consequent disease burden in terms of DALYs derived (Table 2), it is expected that in the future the number of DALYs and the associated HCC due to aflatoxins exposure should increase. A quantification of the health impact of this exposure is crucial to better raise awareness among policy makers for the need to establish preventive measures that could protect populations. Predictions concering the risks to society connected to weather-driven hazards were recently repored. Forzier: et al. (2017) estimated that about 350 million Europeans could be exposed to harnful climate extremes on an annual basis by the end of this century, with a 50 - imes increase in fatalities compared with now, unless global warming is curbed as a matter of urgency and appropriate adaptation measures are taken. The same authors considered climate change as the dominant driver for the projected trenids, accounting for more than $90 \%$ of the rise in the risk to human beings and they justified this considering that Europe is expected to face major changes in the frequency of multiple climate extremes during the coming decades and will be exposed to a progressive and strong increase in overall weather-related hazards (Forzier et al. 2017). In this context, it is of utmost importance to refer that although possible and plausible scenarios, all these estimates and results should be interpreted with caution and as predictions based on modelling approaches. Considering all the scenarios and predictions, it is possible that we are ready to predict and estimate the potential risks and health impact of human exposure to affatoxins in a climate change perspective. In Portugal there is knowledge and mechanisms to characterize the potential impact of climate change on human exposure to aflatoxins, namely there are analytical methodologies to determine toxins in different food products, to assess the human exposure and to derive the potential health risks. However, other aspects should be addressed in the future, namely, i) the inclusion of 
mycotoxins other than aflatoxins in the predictive models, producing outputs that could be used in the risk assessment of different health outcomes; ii) the development of tools that anticipate the contamination levels of food products, since the present models just estimate the risk of crop contamination by some mycotoxins; iii) the consideration of other mycotoxin-cereal grains combinations, that could reflect the combinations mostly occurring in some countries, as for example in Portugal. Another important perspective is the need for political commitment. At global and national level, policy-makers should recognize, understand and prepare actions that reduce the impact of climate change, including those effects highlighted through this article. Actions that coiltribute to i) prevent mycotoxin levels that could represent risk for consumers, ii) survey and monitor the exposure levels of population (e.g. through biomonitoring), and iii) support research studies that could contribute to characterize the associated risks, develop new approaches for dealing with them and prevent some of the potential outcomes, are critical and urgent in a global and national teveis, considering climate change and its health impact as an eminent urequivocal and real risk.

\section{Conclusion}

An integrated approach is advisable to adequately tackle the food safety risks associated with climate change, including perspectives from different disciplines such as natural and social sciences. In addition, and due to the high impact driver of this topic, peliticians and decision-makers should be involved and committed to implement effective measures to reduce the possible consequences and to protect lives. This review article should represent an alert of the potential consequences of one incompletelyexplored perspective of climate change: the health impact of human exposure to aflatoxins. The work should aid in prioritisation of strategies to face the unequal burden of effects of weather-related hazards in Portugal and across Europe. 


\section{Acknowledgments}

This research was performed under National Institute of Health Dr. Ricardo Jorge (Projeto Incentivo de Estudos de Biomonitorização Humana de Âmbito Nacional | BioMAN, BioMAN/DAN/01) and CESAM by the Portuguese Foundation for Science and Technology (FCT) (UID/AMB/50017/2013), through national funds, and the cofunding by the FEDER (POCI-01-0145-FEDER-00763), within the PT2020 Partnership Agreement and Compete 2020.

\section{References:}

Abrunhosa L, Morales H, Soares C, Calado T, Vila-Chã AS, Fereira M, Venâncio A. 2016. A Review of Mycotoxins in Food and Feed Products in Portugal and Estimation of Probable Daily Intakes. Crit Rev Food Sci Nutr [Internet]. 56́:249-265. Available from: http://www.ncbi.nlm.nih.gov/pubmed/24987806

Alvito PC, Sizoo E a., Almeida CMM, van Egmond HF. 2010. Occurrence of aflatoxins and ochratoxin A in baby foods in Portugal. Food Anal Methods. 3:22-30.

Assunção R, Silva MJJ, Alvito P. 2016. Challenges in risk assessment of multiple mycotoxins in food. World Mycotoxin J [Internet]. 9:791-811. Available from: http://www.wageningenacademic.com/doi/10.3920/WMJ2016.2039

Assunção R, Vasç E, Nunes B, Loureiro S, Martins C, Alvito P. 2015. Singlecompound and cumulative risk assessment of mycotoxins present in breakfast cereals consumed by childaren from Lisbon region, Portugal. Food Chem Toxicol [Internet]. [cited 2015 Nov 15]; 86:274-281. Available from: htin///whw.ncbi.nlm.nih.gov/pubmed/26545619 Baranyi N, Kocsubé S, Varga J. 2015. Aflatoxins: Climate change and biodegradation. Curr Opin Food Sci [Internet]. 5:60-66. Available from: http://linkinghub.elsevier.com/retrieve/pii/S221479931500123X

Battilani P, Rossi V, Giorni P, Pietri A, Gualla A, Van der Fels-Klerx HJ, Booij CJH, Moretti A, Logrieco A, Toscano P, et al. 2012. Modelling, predicting and mapping the emergence of aflatoxins in cereals in the EU due to climate change. Scientific report submitted to EFSA [Internet]. [place unknown]. Available from: 
http://www.efsa.europa.eu/en/supporting/pub/en-223

Battilani P, Toscano P, Van der Fels-Klerx HJ, Moretti A, Camardo Leggieri M, Brera C, Rortais A, Goumperis T, Robinson T. 2016. Aflatoxin B1 contamination in maize in Europe increases due to climate change. Sci Rep [Internet]. 6:24328. Available from: http://www.nature.com/articles/srep24328

Blaney BJ, K'Keeffe K, Bricknell LK. 2008. Managing mycotoxins in maize: case studies. Aust J Exp Agric [Internet]. 48:351. Available from: http://www.publish.csiro.au/?paper=EA06095

Boddy L. 1984. The micro-environment of basidiomycete mycelia in temperate deciduous woodlands. In: Jennings DH, Rayner ADM, editors. Ecøl Physioi Fungal Mycelium. Cambridge: Cambridge University Press; p. 261-28?.

Bunyavanich S, Landrigan CP, McMichael AJ, Epstein PR. 2003. The Impact of Climate Change on Child Health. Ambul Pediatr [Internet] 3:44-52. Available from: http://linkinghub.elsevier.com/retrieve/pii/S1530156705602237

Campos I, Guerra J, Gomes JF, Schmidt L, Alves F, V1zinho A, Lopes GP. 2017. Understanding climate change policy and action in Portuguese municipalities: A survey. Land use policy [Internet]. 62:68-78. A valiabie from: http://dx.doi.org/10.1016/j.lardüsepo! .2016.12.015

Carvalho A, Schmidt L, Santos FD, Delicado A. 2014. Climate change research and policy in Portugal. Wiey Interdiscip Rev Clim Chang [Internet]. 5:199-217. Available from: http://doi. wiley com/10.1002/wcc. 258

Casimiro E, Calheiros J, Santos FD, Kovats S. 2006. National Assessment of Human Health Impacts of Climate Change in Portugal: Approach and Key Findings. Environ Fealth Perspect [Internet]. 114:1950-1956. Available from: http://y/v/w.ncbi.nlm.nih.gov/pmc/articles/PMC1764176/

FAST. 2003. Council for Agricultural Science and Technology - Task force report. [place unknown].

Choi J, Aarøe Mørck T, Polcher A, Knudsen LE, Joas A. 2015. Review of the state of the art of human biomonitoring for chemical substances and its application to human exposure assessment for food safety. EFSA Support Publ [Internet]. 12:321 pp. Available from: http://onlinelibrary.wiley.com/doi/10.2903/sp.efsa.2015.EN-724/epdf 
Devleesschauwer B, Haagsma JA, Angulo FJ, Bellinger DC, Cole D, Döpfer D, Fazil A, Fèvre EM, Gibb HJ, Hald T, et al. 2015. Methodological Framework for World Health Organization Estimates of the Global Burden of Foodborne Disease.Kretzschmar MEE, editor. PLoS One [Internet]. 10:e0142498. Available from:

http://dx.plos.org/10.1371/journal.pone.0142498

Dimitrieska-Stojković E, Stojanovska-Dimzoska B, Ilievska G, Uzunov R, Stojković G, Hajrulai-Musliu Z, Jankuloski D. 2016. Assessment of aflatoxin contamination in raw milk and feed in Macedonia during 2013. Food Control [Internet]. 59:201-205. Available from: http://linkinghub.elsevier.com/retrieve/pii/S0956713515902728

Dobolyi C, Sebők F, Varga J, Kocsubé S, Szigeti G, Baranyi N, Széesi Á, Tóth B, Varga M, Kriszt B, et al. 2013. Occurrence of aflatoxin producing Asnergillus flavus isolates in maize kernel in Hungary. Acta Aliment [Internet]. 42:451-159. Available from: http://www.akademiai.com/doi/abs/10.1556/AAlim.42.2013.3.18

Duarte SC, Almeida AM, Teixeira AS, Pereira AL, Falcao AC, Pena A, Lino CM. 2013. Aflatoxin M1 in marketed milk in Portugal. A ssessment of human and animal exposure. Food Control [Internet]. 30:411-41 $\lambda$. Available from: http://dx.doi.org/10.1016/j.foodcont.2012.08.002

EFSA. 2010. Opinion of the screntific panei on contaminants in the food chain on a request from the commission related to the potential increase of consumer health risk by a possible increase of the existing inaximum levels for aflatoxins in almonds, hazelnuts and pis. : $1-127$.

European Commission. 2006. Commission Regulation (EC) No 1881/2006 of 19 December 2006 setting maximum levels for certain contaminants in foodstuffs. Off J Eur Union [Ince net]. [cited 2015 Dec 10]; L 364/5. Available from: http://eurlex.europa.eu/legal-content/en/ALL/?uri=CELEX:32006R1881

European Commission. 2017. RASFF - The Rapid Alert System for Food and Feed 2016 annual report [Internet]. Luxembourg. Available from:

http://ec.europa.eu/food/safety/rasff/docs/rasff_annual_report_2013.pdf

European Food Safety Authority. 2007. Opinion of the scientific panel on contaminants in the food chain on a request from the commission related to the potential increase of consumer health risk by a possible increase of the existing maximum levels for aflatoxins in almonds, hazelnuts and pis. EFSA J [Internet]. [cited 2015 Dec 26]; 446:1- 
127. Available from:

http://www.efsa.europa.eu/sites/default/files/scientific_output/files/main_documents/44 6.pdf

European Food Safety Authority. 2010. Management of left- censored data in dietary exposure assessment of chemical substances. EFSA J [Internet]. 8:1-96. Available from: http://doi.wiley.com/10.2903/j.efsa.2010.1557

European Food Safety Authority. 2013. International Frameworks Dealing with Human Risk Assessment of Combined Exposure to Multiple Chemicals. EFSA J [Internet]. 11:3313. Available from: http://www.efsa.europa.eu/en/efsajournal/pub/3313.htn: Van der Fels-Klerx HJ, Liu C, Battilani P. 2016. Modelling climate change impacts on mycotoxin contamination. World Mycotoxin J [Internet]. 9:1-10. Avallable from: http://www.wageningenacademic.com/doi/10.3920/WMJ2016.2056

van der Fels-Klerx HJ, Olesen JE, Naustvoll L-J, Friocout: Y, Niengelers MJB, Christensen JH. 2012. Climate change impacts on naturai toxins in food production systems, exemplified by deoxynivalenol in wheat and diarrhetic shellfish toxins. Food Addit Contam Part A [Internet]. 29:1647-16:9. A vailable from: http://www.tandfonline.com/doi/abs/10.1080/19440049.2012.714080

Fonseca D, Carvalho MJ, Masta-Ånmeida M, Melo-Gonçalves P, Rocha A. 2016. Recent trends of extreme temperature indices for the Iberian Peninsula. Phys Chem Earth, Parts A/B/C [Witernet]. 94,66-76. Available from: http://dx.doi.org/10.1016/j.pce.2015.12.005

Forzieri G, Cescatti A, e Silva FB, Feyen L. 2017. Increasing risk over time of weatherrelated hazards to the European population: a data-driven prognostic study. Lancet Plañct Heal[rinternet]. 1:e200-e208. Available from: http://linkinghub.elsevier.com/retrieve/pii/S2542519617300827

Gibb H, Devleesschauwer B, Bolger PM, Wu F, Ezendam J, Cliff J, Zeilmaker M, Verger P, Pitt J, Baines J, et al. 2015. World Health Organization estimates of the global and regional disease burden of four foodborne chemical toxins, 2010: a data synthesis. F1000Research [Internet]. 4:1-12. Available from: http://f1000research.com/articles/4$1393 / \mathrm{v} 1$

Giorgi F. 2006. Climate change hot-spots. Geophys Res Lett [Internet]. 33:L08707. 
Available from: http://doi.wiley.com/10.1029/2006GL025734

Havelaar AH, Kirk MD, Torgerson PR, Gibb HJ, Hald T, Lake RJ, Praet N, Bellinger DC, de Silva NR, Gargouri N, et al. 2015. World Health Organization Global Estimates and Regional Comparisons of the Burden of Foodborne Disease in 2010.von Seidlein L, editor. PLOS Med [Internet]. 12:e1001923. Available from:

http://dx.plos.org/10.1371/journal.pmed.1001923

Heyndrickx E, Sioen I, Huybrechts B, Callebaut A, De Henauw S, De Saeger S. 2015 Human biomonitoring of multiple mycotoxins in the Belgian population: Resulis of the BIOMYCO study. Environ Int [Internet]. [cited 2016 Feb 29]; 84:82-89. Availab!e from: http://linkinghub.elsevier.com/retrieve/pii/S0160412015300015

IARC. 2012. IARC monographs on the evaluation of carcinogenic risks to humans. A review of human carcinogens: chemical agents and related occupations. Vol. 100F:225248.

International Agency for Research on Cancer. 2002. IARC Monographs on the Evaluation of Carcinogenic Risks to Humars [Internet] Lyon, France: IARC Press. Available from: http://monographs.iarc.fr/ENG/Monographs/vol82/mono82.pdf International Agency for Research on Cancer/'World Health Organization (IARC/WHO). 2016. Cancer Fact Sheets: Liver Cancer [Internet]. Available from: http://gco.iarc.fr/today/dala/pdf/fact-sheets/cancers/cancer-fact-sheets-7.pdf IPCC. 2007. Climate Change 2007: Synthesis Report. Contribution of Working Groups I, II and III to the Fourth Assessment Report of the Intergovernmental Panel on Climate Change. Geneva, switzerland.

IPCC. 2014 Climate Change 2014: Synthesis Report. Contribution of Working Groups I, II and III to the Fifth Assessment Report of the Intergovernmental Panel on Climate Change [Internet]. Geneva, Switzerland. Available from: hit p://www.ipcc.ch/report/ar5/syr/

Janić Hajnal E, Kos J, Krulj J, Krstović S, Jajić I, Pezo L, Šarić B, Nedeljković N. 2017. Aflatoxins contamination of maize in Serbia: the impact of weather conditions in 2015. Food Addit Contam Part A [Internet]. 34:1999-2010. Available from: http://dx.doi.org/10.1080/19440049.2017.1331047 Jones S. 2017. Portugal forest fires under control after more than 60 deaths. Guard 
[Internet]. Available from: https://www.theguardian.com/world/2017/jun/22/portugalforest-fires-under-control

Kos J, Mastilović J, Hajnal EJ, Šarić B. 2013. Natural occurrence of aflatoxins in maize harvested in Serbia during 2009-2012. Food Control [Internet]. 34:31-34. Available from: http://linkinghub.elsevier.com/retrieve/pii/S0956713513001771

Leblanc J-C, Tard A, Volatier J-L, Verger P. 2005. Estimated dietary exposure to principal food mycotoxins from The First French Total Diet Study. Food Addit Contam. 22:652-672.

Leggieri M, Bertuzzi T, Pietri A, Battilani P. 2015. Mycotoxin occurren ce in màize produced in Northern Italy over the years 2009-2011: focus on the role of cron related factors MARCO. Phytopathol Mediterr. 54:212-221.

Levic J, Gosic-Dondo S, Ivanovic D, Stankovic S, Krnjaja V, Bocarov-Stancic A, Stepanic A. 2013. An outbreak of Aspergillus species in response to environmental conditions in Serbia. Pestic i fitomedicina [Internet]. 28:167-179. Available from: http://www.doiserbia.nb.rs/Article.aspx?ID--1820-39491303167L

Liu Y, Wu F. 2010. Global Burden of Aflatoxin-induced Hepatocellular Carcinoma: A Risk Assessment. Environ Health Perspect [Irternet]. 118:818-824. Available from: http://ehp.niehs.nih.gov/0901388

Logrieco AF, Moretti A. 2008. Between emerging and historical problems: an overview of the main toxigen; fungi and mycotoxin concerns in Europe. In: Mycotoxins Detect methods, Manag public Heal Agric trade [Internet]. Wallingford: CABI; p. 139-153. Available from: http://www.cabi.org/cabebooks/ebook/20083189569

Magan P. Thedma A, Aldred D. 2011. Possible climate-change effects on mycotoxin contamination of food crops pre- and postharvest. Plant Pathol [Internet]. [cited 2015 Dec 28]: 60:150-163. Available from: http://doi.wiley.com/10.1111/j.1365$3059.2010 .02412 . x$

Martins C, Assunção R, Cunha SC, Fernandes JO, Jager A, Petta T, Oliveira CA, Alvito P. 2018. Assessment of multiple mycotoxins in breakfast cereals available in the Portuguese market. Food Chem [Internet]. 239:132-140. Available from: http://linkinghub.elsevier.com/retrieve/pii/S0308814617310701 Martins HM, Magalhães SA, Almeida I, Marques M. 2007. Aflatoxin M1 determination 
in cheese by immunoaffinity column clean-up coupled to high-performance liquid chromatography. Rev Port Ciências Veterinárias. 102:321-325.

Martins HM, Marques M, Almeida I, Guerra MM, Bernardo F. 2008. Mycotoxins in feedstuffs in Portugal: an overview. Mycotoxin Res [Internet]. 24:19-23. Available from: http://link.springer.com/10.1007/BF02985266

Milani J. 2013. Ecological conditions a ff ecting mycotoxin production in cereals : a review. Vet Med (Praha). 58:405-411.

Miller JD. 2008. Mycotoxins in small grains and maize: Old problems, new chalienges Food Addit Contam Part A [Internet]. 25:219-230. Available from:

http://www.tandfonline.com/doi/abs/10.1080/02652030701744520

Miraglia M, Marvin HJP, Kleter GA, Battilani P, Brera C, Coni E, Cubadda F, Croci L, De Santis B, Dekkers S, et al. 2009. Climate change and food safety: An emerging issue with special focus on Europe. Food Chem Toxicol [hiternet]. 47:1009-1021. Available from: http://dx.doi.org/10.1016/j.fct.2009.02.005

Munkvold GP, Desjardins AE. 1997. Fumsnisins in Maize: Can We Reduce Their Occurrence? Plant Dis [Internet]. 81:556-565 Avallable from: http://apsjournals.apsnet.org/doi/10.1094/FDî́S.1997.81.6.556 Murray CJL, Lopez AD. 2013. Measuring the Global Burden of Disease. N Engl J Med [Internet]. 369:448-457. Available from:

http://www.nejm.org/sioi/10.1056/NEJMra1201534

Murray CJL, Lopez AD. 2017. Measuring global health: motivation and evolution of the Global Burden of Disease Study. Lancet [Internet]. 390:1460-1464. Available from: http:/1inkinghub elsevier.com/retrieve/pii/S014067361732367X

de Nijs M, Mengelers MJB, Boon PE, Heyndrickx E, Hoogenboom LAP, Lopez P, Mol HGJ. 2016. Strategies for estimating human exposure to mycotoxins via food. World Mycotoxin J [Internet]. [cited 2016 Oct 16]:1-16. Available from: http://www.wageningenacademic.com/doi/10.3920/WMJ2016.2045

Paterson RRM, Lima N. 2010. How will climate change affect mycotoxins in food? Food Res Int [Internet]. 43:1902-1914. Available from: http://dx.doi.org/10.1016/j.foodres.2009.07.010 Paterson RRM, Lima N. 2011. Further mycotoxin effects from climate change. Food 
Res Int [Internet]. 44:2555-2566. Available from:

http://dx.doi.org/10.1016/j.foodres.2011.05.038

Payne GA. 1998. Process of contamination by aflatoxin-producing fungi and their impact on crops. In: Sinha KK, Bhatnagar D, editors. Mycotoxins Agric Food Saf. New York: Marcel Decker Inc; p. 279-300.

Piva G, Battilani P, Pietri A. 2006. Emerging issues in southern Europe: Aflatoxins in Italy. In: Barug D, Bhatnagar D, van Egmond HP, van der Kamp JW, van Osenbruggen WA, Visconti A, editors. mycotoxin Factb [Internet]. The Netherlands: Wageningen Academic Publishers; p. 139-153. Available from:

http://www.wageningenacademic.com/doi/book/10.3920/978-90-8686-587-1

Pleadin J, Vulić A, Perši N, Škrivanko M, Capek B, Cvetnić Ž. 2014. Aflatoxin B1 occurrence in maize sampled from Croatian farms and fee factories during 2013. Food Control [Internet]. 40:286-291. Available from:

http://linkinghub.elsevier.com/retrieve/pii/S0956713513006์ك34

Ramos A, Trigo R, Santo F. 2011. Evolution of extreme temperatures over Portugal: recent changes and future scenarios. Clim Res [internet]. 48:177-192. Available from: http://www.int-res.com/abstracts/cr/v48/nz-3/p177-192/

Robens J, Cardwell K. 2003. The Costs of Mycotoxin Management to the USA: Management of Aflatoxins in the United States. J Toxicol Toxin Rev [Internet]. 22:139-152. Availabie from. haty://www.tandfonline.com/doi/full/10.1081/TXR120024089

Rodrigues P, Venâncio A, Lima N. 2012. Aflatoxigenic Fungi and Aflatoxins in Portuguese Almonds. Sci World J [Internet]. 2012:1-9. Available from: http. II w w hildawi.com/journals/tswj/2012/471926/

Sabino R., Faísca VM, Carolino E, Veríssimo C, Viegas C. 2012. Occupational Exposure to Aspergillus by Swine and Poultry Farm Workers in Portugal. J Toxicol Environ Heal Part A [Internet]. 75:1381-1391. Available from:

https://www.tandfonline.com/doi/full/10.1080/15287394.2012.721170

Santos FD. 2017. Climate Change and Food Security. In: ICFC 2017 B Abstr (2nd Int Conf Food Contam [Internet]. Braga, Portugal: Universidade do Minho; p. 9. Available from: http://www.icfc2017.uminho.pt/index.php/call-for-abstracts/book-of-abstracts 
Statistics Portugal/Instituto Nacional de Estatística (INE). 2016. Statistical data [Internet]. Available from:

https://www.ine.pt/xportal/xmain?xpid=INE\&xpgid=ine_cont_inst\&ine_smenu.boui=1 $3918434 \&$ INST $=53864 \& x$ lang $=$ en

Strosnider H, Azziz-Baumgartner E, Banziger M, Bhat R V., Breiman R, Brune M-N, DeCock K, Dilley A, Groopman J, Hell K, et al. 2006. Public Health Strategies for Reducing Aflatoxin Exposure in Developing Countries: A Workgroup Report. Environ Health Perspect [Internet]. 114:1898-1903. Available from:

http://www.ncbi.nlm.nih.gov/pmc/articles/PMC1764136/

Tabuc C, Marin D, Guerre P, Sesan T, Bailly JD. 2009. Molds and Mycotoxin Content of Cereals in Southeastern Romania. J Food Prot [Internet]. 72:662-065. Available from: http://www.ncbi.nlm.nih.gov/pubmed/19343960

Tirado MC, Clarke R, Jaykus LA, McQuatters-Gollop A, Frank IA. 2010. Climate change and food safety: A review. Food Res Int [Internet]. 43.1745-1765. Available from: http://dx.doi.org/10.1016/j.foodres.2010.07.003

UNFCCC. 2015. Conference of the Parties (COP). Adoption of the Paris Agreement. Geneva, Switzerland.

Viegas C, Faria T, Carolino E, Sabino R, Gomes A, Viegas S. 2016. Occupational exposure to fungi and parcicles in animal feed industry. Med Pr [Internet]. 67:143-154. Available from: http: iww.jo/rnalssystem.com/medpr/Occupational-exposure-tofungi-and-particles-in-one-Prrtuguese-animal-feed-industry-a-preliminarystudy,60085,0,2.html

Viegas C, Gonies AQ, Abegão J, Sabino R, Graça T, Viegas S. 2014. Assessment of Fyngal Contamination in Waste Sorting and Incineration-Case Study in Portugal. J Toxicol Environ Heal Part A [Internet]. 77:57-68. Available from: http:II Www.tandfonline.com/doi/abs/10.1080/15287394.2014.865583

Viegas C, Meneses M, Viegas S. 2016. Climate changes influence in occupational exposure to fungi and mycotoxins. In: Occup Saf Hyg IV [Internet]. [place unknown]: CRC Press; p. 11-15. Available from: http://www.crcnetbase.com/doi/10.1201/b211724\%0Ahttp://hdl.handle.net/10400.21/6306

Viegas S, Veiga L, Almeida A, dos Santos M, Carolino E, Viegas C. 2016. 
Occupational Exposure to Aflatoxin B1 in a Portuguese Poultry Slaughterhouse. Ann Occup Hyg [Internet]. 60:176-183. Available from:

https://academic.oup.com/annweh/article-lookup/doi/10.1093/annhyg/mev077

Viegas S, Veiga L, Figueiredo P, Almeida A, Carolino E, Viegas C. 2014. Assessment of Workers' Exposure to Aflatoxin B1 in a Portuguese Waste Industry. Ann Occup Hyg [Internet]. 59:173-181. Available from:

https://academic.oup.com/annweh/article/59/2/173/2740598/Assessment-of-WorkersExposure-to-Aflatoxin-B1-in

Viegas S, Veiga L, Figueiredo P, Almeida A, Carolino E, Viegas C. 2015. Assessment of Workers' Exposure to Aflatoxin B1 in a Portuguese Waste Industriy Ann Occup Hyg [Internet]. 59:173-181. Available from:

https://academic.oup.com/annweh/article/59/2/173/2740598/Assessmient-of-WorkersExposure-to-Aflatoxin-B1-in

Viegas S, Veiga L, Figueredo P, Almeida A, Caroline E, Sảbino R, Veríssimo C, Viegas C. 2013a. Occupational Exposure to Aflatoxin B 1 in Swine Production and Possible Contamination Sources. J Toxicoi Environ Heal Part A [Internet]. 76:944-951. Available from: http://www.tandfonline.con/ajoi/abs/10.1080/15287394.2013.826569

Viegas S, Veiga L, Figueredo P, Ainneida A, Carolino E, Sabino R, Veríssimo C, Viegas C. 2013b. Occupational exprosure to aflatoxin B 1 : the case of poultry and swine production. World Mycoroxin J linternet]. 6:309-315. Available from: http://www.wageningenacadernic.com/doi/10.3920/WMJ2012.1531

Viegas S, V£iga L, Malia-Vacas J, Sabino R, Figueredo P, Almeida A, Viegas C, Caroling E. 2012. Occupational Exposure to Aflatoxin (AFB 1 ) in Poultry Production. J Toxicoi Environ Heal Part A [Internet]. 75:1330-1340. Available from: attps://ww w.tandfonline.com/doi/full/10.1080/15287394.2012.721164 Watts iN, Adger WN, Agnolucci P, Blackstock J, Byass P, Cai W, Chaytor S, Colbourn T, Collins M, Cooper A, et al. 2015. Health and climate change: policy responses to protect public health. Lancet [Internet]. 386:1861-1914. Available from: http://linkinghub.elsevier.com/retrieve/pii/S0140673615608546 WHO. 2008. The Global Burden of Disease: 2004 Update [Internet]. Geneva, Switzerland. Available from: http://www.who.int/healthinfo/global_burden_disease/2004_report_update/en/index.ht 
$\mathrm{ml}$

Wild CP, Gong YY. 2010. Mycotoxins and human disease: a largely ignored global health issue. Carcinogenesis [Internet]. 31:71-82. Available from:

https://academic.oup.com/carcin/article-lookup/doi/10.1093/carcin/bgp264

World Health Organization. 2015. WHO estimates of the global burden of foodborne diseases: foodborne disease burden epidemiology reference group 2007-2015 [Internei]. Geneva, Switzerland: World Health Organization. Available from: http://www.who.int/foodsafety/publications/foodborne_disease/fergreport/en/ Wu F, Groopman JD, Pestka JJ. 2014. Public Health Impacts of Foodbcrne Mycotexins. Annu Rev Food Sci Technol [Internet]. 5:351-372. Available from: http://www.ncbi.nlm.nih.gov/pubmed/24422587

Table 1. Dietary exposure assessment of Portuguese population to aflatoxins and their occurrence in food products. The presented studies were published between 2007 and 2017.

Table 2. Disease burien estimates for hepatocellular carcinoma (HCC) considering estimated Portuguese dietary exposure to aflatoxins. 
Table 3. Dietary exposure assessment of Portuguese population to aflatoxins and their occurrence in food products The presented studies were published between 2007 and 2017.

\begin{tabular}{|c|c|c|c|c|c|c|c|c|}
\hline & & & \multicolumn{4}{|c|}{ Occurrence in food data } & \multicolumn{2}{|c|}{ Exposure data } \\
\hline Reference & Mycotoxin & Food product & $\begin{array}{c}\text { LOD } \\
(\mu \mathrm{g} / \mathrm{Kg} ; \mu \mathrm{g} / \mathrm{L})\end{array}$ & $\begin{array}{l}\text { Positive } \\
\text { Samples }\end{array}$ & $\begin{array}{l}\text { Mean Concentration } \\
\qquad(\mu \mathrm{g} / \mathrm{Kg} ; \mu \mathrm{g} / \mathrm{L})\end{array}$ & $\begin{array}{l}\text { Range of Concentrati } \\
(\mu \mathrm{g} / \mathrm{Kg} \cdot \mu \mathrm{g} / \mathrm{L})\end{array}$ & $\begin{array}{l}\text { Population } \\
\text { group }\end{array}$ & $\begin{array}{c}\text { Exposure } \\
\text { assessment - PDI } \\
\text { (ng/Kg bw/day) }\end{array}$ \\
\hline $\begin{array}{l}\text { Martins et al. } \\
\text { (2007) }\end{array}$ & $\mathrm{AFM}_{1}$ & Cheese $^{1,2}$ & 0.005 & $3 / 48(6.3 \%)$ & 0.010 & & - & - \\
\hline $\begin{array}{l}\text { EFSA } \\
(2007)\end{array}$ & $\begin{array}{c}\text { Sum of } \mathrm{AFB}_{1}, \mathrm{AFB}_{2}, \\
\mathrm{AFG}_{1}, \mathrm{AFG}_{2}\end{array}$ & $\begin{array}{l}\text { hazelnuts, almonds, } \\
\text { pistachios, other nuts, maize, } \\
\text { oilseeds, dried fruits, spices }{ }^{1}\end{array}$ & - & - & - & & $\begin{array}{c}\text { Adults, } \\
\text { children, } \\
\text { vegetarians }\end{array}$ & $0.838-1.934^{*}$ \\
\hline $\begin{array}{l}\text { Alvito et al. } \\
\text { (2010) }\end{array}$ & $\begin{array}{l}\mathrm{AFM}_{1} \\
\mathrm{AFB}_{1}\end{array}$ & $\begin{array}{l}\text { Infant cereals }^{1,2} \\
\text { Infant formulae }^{1,2} \\
\text { Infant cereals }^{1,2} \\
\text { Infant formula }^{1,2}\end{array}$ & $\begin{array}{l}0.004 \\
0.001\end{array}$ & $\begin{array}{l}4 / 19(21.0 \%) \\
6 / 7(85.7 \%) \\
6 / 19(32.0 \%) \\
1 / 7(14.3 \%)\end{array}$ & $\mathrm{NR}$ & $\begin{array}{l}<\mathrm{LOD}-0.018 \\
<\mathrm{LOD}-0.041 \\
<\mathrm{LOD}-0.009 \\
<\mathrm{LOD}-0.003\end{array}$ & - & - \\
\hline $\begin{array}{l}\text { Duarte et al. } \\
\text { (2013) }\end{array}$ & $\mathrm{AFM}_{1}$ & Milk $^{1,2}$ & 0.005 & & & $<$ LOD -0.069 & Adults & 0.080 \\
\hline $\begin{array}{l}\text { Assunção et al. } \\
\text { (2015) }\end{array}$ & $\begin{array}{l}\mathrm{AFB}_{1} \\
\mathrm{AFB}_{2} \\
\mathrm{AFG}_{1} \\
\mathrm{AFM}_{1}\end{array}$ & Breakfast cereals $^{1,2}$ & - & & $\begin{array}{l}- \\
- \\
-\end{array}$ & $\begin{array}{l}- \\
- \\
- \\
-\end{array}$ & $\begin{array}{l}\text { Children } \\
1-3 \text { years }\end{array}$ & $\begin{array}{l}0.012 \\
0.001 \\
0.003 \\
0.005\end{array}$ \\
\hline $\begin{array}{l}\text { Abrunhosa et al. } \\
\text { (2016) }\end{array}$ & $\begin{array}{c}\text { Sum of } \mathrm{AFB}_{1}, \mathrm{AFB}_{2}, \\
\qquad \mathrm{AFG}_{1}, \mathrm{AFG}_{2} \\
\mathrm{AFM}_{1}\end{array}$ & $\begin{array}{l}\text { Pistachio, peanuts, dry figs, } \\
\text { spices, almonds, pig liver, } \\
\text { other nuts }^{1} \\
\text { Milk, powdered milk, } \\
\text { yoghurt, cheese }^{1,2}\end{array}$ & & & - & - & Adults & $\begin{array}{l}0.501 \\
0.073\end{array}$ \\
\hline $\begin{array}{l}\text { Martins et al. } \\
\text { (2018) }\end{array}$ & $\begin{array}{l}\mathrm{AFB}_{1} \\
\mathrm{AFB}_{2} \\
\mathrm{AFG}_{1} \\
\mathrm{AFG}_{2} \\
\mathrm{AFM}_{1}\end{array}$ & Breakfast & $\begin{array}{l}0.063 \\
0.001 \\
0.006 \\
0.010 \\
0.011\end{array}$ & $\begin{array}{c}18 / 26(69 \%) \\
7 / 26(27 \%) \\
1 / 26(4 \%) \\
0 / 26(0 \%) \\
3 / 26(12 \%)\end{array}$ & $\begin{array}{c}0.013 \\
0.004 \\
0.013 \\
\text { NA } \\
0.013\end{array}$ & $\begin{array}{c}<\mathrm{LOD}-0.130 \\
<\mathrm{LOD}-0.011 \\
<\mathrm{LOD}-0.013 \\
\quad \mathrm{NA} \\
<\mathrm{LOD}-0.024\end{array}$ & $\begin{array}{l}- \\
- \\
- \\
- \\
-\end{array}$ & $\begin{array}{l}- \\
- \\
- \\
-\end{array}$ \\
\hline
\end{tabular}


Table 4. Disease burden estimates for hepatocellular carcinoma (HCC) considering Portuguese estimated dietary exposure to aflatoxins.

\begin{tabular}{|c|c|c|c|c|c|}
\hline $\begin{array}{l}\text { Aflatoxin exposure } \\
\text { (reference) }\end{array}$ & $\begin{array}{l}\text { Aflatoxin dietary } \\
\text { exposure level } \\
\left(\text { ng kg bw }^{-1} \text { day }^{-1}\right)\end{array}$ & $\begin{array}{c}\text { Annual Extra } \\
\text { case of HCC }\end{array}$ & $\begin{array}{c}\text { Annual Extra } \\
\text { case of } \mathrm{HCC} \\
\text { per } 100,000\end{array}$ & $\begin{array}{l}\text { Annual } \\
\text { DALY }\end{array}$ & $\begin{array}{c}\text { Annual DALY } \\
\text { per } 100,000\end{array}$ \\
\hline $\begin{array}{l}\text { Europe lower bound } \\
\text { (EFSA 2007) }\end{array}$ & 0.838 & 0.87 & 0.008 & 13.4 & 0.13 \\
\hline $\begin{array}{l}\text { Europe upper bound } \\
\text { (EFSA 2007) }\end{array}$ & 1.934 & 2.00 & 0.019 & 30.9 & 0.30 \\
\hline $\begin{array}{l}\text { Portugal (Abrunhosa } \\
\text { et al. 2016) }\end{array}$ & 0.501 & 0.52 & 0.005 & 8.0 & 0.08 \\
\hline
\end{tabular}




\section{Supplemental material}

\section{Estimated Health impact considering aflatoxin exposure and aflatoxin-related hepatocellular carcinoma}

A population attributable fraction (PAF) approach was used to estimate the number of cases of aflatoxin-related hepatocellular carcinoma (HCC), following the procedure described by (World Health Organization 2015). Within this context, PAF signifies the contribution of a risk factor to a disease or a death. For the present calculations, $\mathrm{HCC}$ was selected as a clinical outcome of the aflatoxin exposure. The excess risk due to aflatoxin exposure was estimated multiplying an aflatoxin cancer potency factor [according to (Liu \& Wu 2010)] by the considered estimated leveis of Portuguese aflatoxin exposure (according to Table 1).

The burden disease associated to aflatoxin expostre was estimated using DisabilityAdjusted Life Years (DALY). DALY summarize the occurrence and impact of morbidity and mortality in a single measure and quantifies the healthy life years lost due to a disease or injury (Devleess.chatwer et al. 2015). DALY were calculated by adding the adjusted number of years ived with disability (YLDs) and the number of years of life lost due to premaiure mortality (YLLs) (Devleesschauwer et al. 2015), calculated by:

$$
\text { DALV }=\left(t_{f} \times d w_{f} \times p_{f}\right)+\left(t_{n f} \times d w_{n f} \times p_{n f}\right)+\left(Y L L \times p_{f}\right)
$$

where $f$ is the duration of disease of fatal cancer in years, $d w_{f}$ is the disability weight 5if fatal cancer, $p_{f}$ is the probability of a cancer being fatal, $t_{n f}$ is the duration of disease of non-fatal cancer in years, $d w_{n f}$ is the disability weight non-fatal cancer, $p_{n f}$ is the probability of a cancer being non-fatal and $Y L L$ is the life years lost due to premature death to a fatal cancer (Jakobsen et al. 2016). $Y L D_{f}$ and $Y L D_{n f}$ were obtained through the first and second terms of the previous equation, respectively. National statistical 
data (obtained at Statistics Portugal, https://www.ine.pt/), HCC cancer data and WHO disability weights $(d w)$ were used to perform these calculations, according to Table S1.

Table S5. Parameters used to calculate Disability-Adjusted Life Years (DALYs) through the summation of adjusted number of years lived with disability (YLDs) and the number of years of life lost due to premature mortality (YLLs).

\begin{tabular}{|c|c|c|}
\hline Parameter & Values & Reference \\
\hline Life expectancy at birth (in years) & 80.62 & (INE 2016) \\
\hline Age of onset of HCC - Portuguese data (in years) & 63.7 & (Silva 2015) \\
\hline Duration of disease of fatal cancer, $t_{f}$ (in years) & 0.5 & 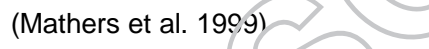 \\
\hline Disability weight of fatal cancer, $d w_{f}$ & 0.508 & alth Organ \\
\hline Probability of a cancer being fatal, $p_{f}$ & 0.92 & \\
\hline Duration of disease of non-fatal cancer, $t_{n f}$ (in years) & 5 & \\
\hline Disability weight of non-fatal cancer, $d w_{n f}$ & 0.294 & tri: Organization 2015) \\
\hline Probability of a cancer being non-fatal, $p_{n f}$ & 0.08 & ai. 1999) \\
\hline
\end{tabular}

References:

Devleesschauwer B, Haagsma IA, Angulo FJ, Bellinger DC, Cole D, Döpfer D, Fazil A, Fèvre EM, Gibb HJ, Hald T, et al. 2015. Methodological Framework for World Health Crganizatien Estimates of the Global Burden of Foodborne Disease.Kretzschmar MEE, editor. PLoS One [Internet]. 10:e0142498.

Availablo from: inttp://dx.plos.org/10.1371/journal.pone.0142498

Jakobsen IS, Gianby K, Knudsen VK, Nauta M, Pires SM, Poulsen M. 2016. Burden of disease of dietary exposure to acrylamide in Denmark. Food Chem Toxicol [Internet]. 90:151-159. Available from: h/tp://dx.doi.org/10.1016/j.fct.2016.01.021

Liu Y, Wu F. 2010. Global Burden of Aflatoxin-Induced Hepatocellular Carcinoma: A Risk Assessment. Environ Health Perspect [Internet]. 118:818-824. Available from: http://ehp.niehs.nih.gov/0901388

Mathers C, Vos T, Stevenson C. 1999. The burden of disease and injuy in Australia. Canberra. 
Silva T. 2015. Evaluation of hepatocellular carcinoma in clinical practice [Internet].

Porto, Portugal: Faculty of Medicine, University of Porto. Available from:

https://sigarra.up.pt/fmdup/pt/pub_geral.pub_view?pi_pub_base_id=35137

Statistics Portugal/Instituto Nacional de Estatística (INE). 2016. Statistical data

[Internet]. Available from:

https://www.ine.pt/xportal/xmain?xpid=INE\&xpgid=ine_cont_inst\&ine_smenu. boui $=13918434 \&$ INST $=53864 \&$ xlang $=$ en

World Health Organization. 2015. WHO estimates of the global burden of foodborne diseases: foodborne disease burden epidemiology reference group 200 $7-2015$ [Internet]. Geneva, Switzerland: World Health Organization. Ava lable from: http://www.who.int/foodsafety/publications/foodborne_disease/fergreport/en/ 